\title{
ENVIRONMENTAL FACTORS PREDISPOSING TO PAIN SYNDROMES AMONG ADOLESCENT GIRLS WITH DIAGNOSED IDIOPATHIC SCOLIOSIS*
}

\author{
Ireneusz M. Kowalski ${ }^{1,2}$, \\ Halina Protasiewicz-Fałdowska ${ }^{1}$, \\ Daria Jóźwiak-Grabysa ${ }^{1,2}$, Wojciech Kiebzak ${ }^{3}$, \\ Daniel Zarzycki ${ }^{4}$, Roman Lewandowski ${ }^{2}$, Józef Szarek ${ }^{5}$ \\ ${ }^{1}$ Department and Clinic of Rehabilitation \\ University of Warmia and Mazury in Olsztyn \\ ${ }^{2}$ Provincial Children's Rehabilitation Hospital in Ameryka near Olsztynek \\ ${ }^{3}$ Institute of Physiotherapy, Jan Kochanowski University in Kielce \\ ${ }^{4}$ Department and Clinic of Orthopaedics and Rehabilitation in Zakopane \\ Collegium Medicum, Jagiellonian University in Cracow \\ ${ }^{5}$ Chair of Pathophysiology \\ Forensic Veterinary Medicine and Administration \\ University of Warmia and Mazury in Olsztyn
}

\begin{abstract}
Idiopathic scoliosis (IS), despite multidirectional therapy, involves a significant impairment of the quality of life of the patients. It is caused by pain syndromes frequently accompanying IS, the etiology of which has not been entirely discovered. The present research on environmental factors predisposing to pain syndromes in girls with IS involved analysis of 54 girls under ambulatory care, aged 14-17 (on average 15.3-years-old \pm 0.99 ). The patients' natural environment was analysed, including time spent in a sedentary position during the day, sleeping time, time spent on physical activity during the week, regularity of meals consumed, as well as the quantitative composition of the diet. The research also concerned the location and characteristics of ailment reported, as well as pain intensity on the Numerical Rating Scale (NRS).
\end{abstract}

prof. Ireneusz M. Kowalski MD, Ph.D. Department and Clinic of Rehabilitation, Faculty of Medical Sciences University of Warmia and Mazury in Olsztyn, e-mail: klinika@ameryka.com.pl

*This article has been partly financed by the research fund for 2009-2012. 
It was found that the most frequent locations of back pain were: lumbar section in 28 persons (51.9\% of the examined population), and thoracic section of the spine - in 21 persons (38.9\% of the examined population). Pain occurring at the same time in the cervical, thoracic and lumbar sections of the spine was reported for 4 persons $(7.4 \%$ of the examined population). Fifty girls $(92.6 \%)$ were aware of controlling their body posture, and 23 persons $(42.6 \%)$ were able to correct it. The group of girls under examination suffering from pain in the lumbar section of the spine was characterized by a longer period of retaining a sedentary position, less time dedicated to any therapeutic rehabilitation programme, higher intensity of pain, and a higher average age than the group with pain in the thoracic section of the spine.

The research proved that patients with pain syndrome located in the lumbar part of the spine were characterized by more time spent in a sedentary position, less time spent on a therapeutic rehabilitation programme, higher intensity of pain and a higher average age than the group suffering from pain in the thoracic section of the spine. The lifestyles of the patients under examination and their lack of awareness of the need to control the body posture can affect the type and intensity of pain.

Key words: idiopathic scoliosis, pain, adolescent girls, environmental factors.

\section{CZYNNIKI ŚRODOWISKOWE PREDYSPONUJĄCE DO ZESPOŁÓW BÓLOWYCH KRĘGOSŁUPA W POPULACJI DZIEWCZĄT ZE SKOLIOZĄ IDIOPATYCZNA}

\section{Abstrakt}

Idiopatyczna skolioza kręgosłupa (ISK), pomimo wielokierunkowej terapii, wiąże się z istotnym obniżeniem jakości życia chorych. Przyczyną tego są często towarzyszące IKS zespoły bólowe, których etiologia nie jest jeszcze całkowicie poznana. Realizując badania nad wskazaniem czynników środowiskowych predysponujących do zespołów bólowych kręgosłupa $\mathrm{u}$ dziewcząt $\mathrm{z}$ ISK, poddano analizie 54 objęte opieką ambulatoryjną dziewczęta w wieku od 14 do 17 lat (średnio 15,3 lat $\pm 0,99$ ). Dokonano analizy środowiska naturalnego pacjentek, m.in.: czasu przebywania w pozycji siedzącej w ciagu doby, czasu trwania snu, ilości czasu przeznaczonego na aktywność ruchowa w ciągu tygodnia oraz regularności spożywanych posiłków, a także składu ilościowego diety. Przedmiotem badań była też lokalizacja i charakterystyka zgłaszanych dolegliwości oraz ocena intensywności bólu według skali numerycznej NRS (Numerical Rating Scale).

Stwierdzono, że najczęstszymi lokalizacjami bólu pleców były odcinki: lędźwiowy u 28 osób (51,9\% populacji badanej) oraz piersiowy kręgosłupa u 21 osób (38,9\% populacji badanej). Ból obejmujący jednocześnie odcinki szyjny, piersiowy oraz lędźwiowy kręgosłupa występował u 4 osób (7,4\% populacji badanej). Świadomość kontroli postawy ciała miało 50 badanych dziewcząt $(92,6 \%)$, a skorygować ja potrafiły 23 osoby $(42,6 \%)$. Grupa badanych dziewcząt $\mathrm{z}$ bólem odcinka lędźwiowego kręgosłupa dłuższy czas przebywała w pozycji siedzącej, mniej czasu poświęcała na program usprawniania terapeutycznego, skarżyła się na większą intensywność bólu i miała wyższą średnią wieku niż grupa z bólem odcinka piersiowego kręgosłupa.

W badaniach wykazano, że pacjenci z zespołem bólowym zlokalizowanym w części lędźwiowej kręgosłupa dłuższy czas przebywali w pozycji siedzącej, mniej czasu poświęcali na program usprawniania terapeutycznego oraz zgłaszali większą intensywność bólu i mieli wyższą średnią wieku w porównaniu z grupa z bólem odcinka piersiowego kręgosłupa. Tryb życia chorych objętych badaniem i brak świadomości kontroli postawy może mieć wpływ na rodzaj i intensywność dolegliwości bólowych.

Słowa kluczowe: skolioza idiopatyczna, ból, dorastające dziewczęta, czynniki środowiskowe. 


\section{INTRODUCTION}

Research and analyses concerning the quality of life in relation to environmental factors of patients with IS remain a valid area of study. Prevention of the development of spinal curvatures is the main aim of preventive treatment (WiŚNIEWSKA et al. 2006). Paradoxically, research projects on the effectiveness of preventive treatment are more difficult when children and teenagers receive much medical and social care (GRIVAs et al. 2006). Currently, it seems impossible to compare such patients to a group of untreated patients, deprived of even natural physical activity and unintentional prophylactic activities, such as physical education lessons, amateur sport or recreational swimming (GolDBERG et al. 1994, WeINSTEIN et al. 2003).

IS is a problem concerning a large group of adolescents, particularly girls (Ponseti, Freidman 1950, Weinstein et al. 2003). In spite of multidirectional, preventive and (increasingly more often) invasive therapy, this condition involves a significant impairment in the life quality of the IS patients caused by pain syndromes, which often accompany the illness (PonseTI, FreIDMAN 1950).

\section{MATERIAL AND METHODS}

The aim of the research has been to indicate which environmental factors predispose girls with idiopathic scoliosis to spinal pain syndromes.

The research involved examination of 54 girls aged 14-17 (on average 15.3 years \pm 0.99 ), including 28 girls with pain in the lumbar section (average age 15.39 years \pm 0.99 ), 22 girls with pain in the thoracic section (average age 14.73 years \pm 0.98 ) and 4 girls with pain in cervical, thoracic and lumbar sections (average age 15.75 years \pm 1.25 ). Further analysis concerned only the girls with pain in lumbar and thoracic sections of the spine. All persons examined were under ambulatory care because of IS. In the whole group, first grade IS was diagnosed in 44 persons and second grade IS in the remaining 10 persons. The data obtained underwent bidirectional analysis. The first part of the research was to analyse the natural environment of patients, including the time spent in a sedentary position during the day, sleeping time, time spent on physical activity during the week and regularity of meals consumed, as well as the quantity composition of the diet. The second epart included location and characteristics of the reported ailment as well as the intensity of pain on the Numerical Rating Scale (NRS), in which self-evaluation of pain is specified using a scale of 0-10 points. On this scale, zero point means no pain, while 10 points describe the pain of the highest intensity. Attention was also paid to the programme of therapeutic rehabilitation applied, as well as to the patients' awareness of the body posture control. 
The data for our analyses were obtained with a purpose-designed survey, which included nine points:

1) age of the patient,

2) time spent in a sedentary position during the day:

a) at school,

b) at home,

c) during extracurricular classes;

3) sleeping time per 24 hours,

4) regular meal times,

5) eating habits,

6) duration of physical activity in 1 week:

a) lessons of physical education at school,

b) additional extracurricular classes,

c) physical rehabilitation programme,

d) other;

7) numerical rating scale of the pain,

8) characteristics and location of the back pain:

a) cervical section,

b) thoracic section,

c) lumbar section,

9) body posture awareness.

Whenever atypical deformations of the spine are suspected, the cause and character of the ailment should be thoroughly searched for and treated as an interdisciplinary problem. In such cases, specialist diagnostic tests was performed apart from an X-ray examination, for example computer tomography (TK and TK $3 \mathrm{D}$ ) and magnetic resonance (MRI), which make it possible to precisely describe the deformation, its location and possible changes to the vertebral canal, intervertebral foramens as well as locations of intervertebral discs.

The results obtained during our study were subjected to statistical analysis in order to calculate the means and standard deviation.

\section{RESULTS}

The girls suffering from pain in the thoracic section spent on average 11.02 hours in a sedentary position, while girls suffering from pain of the lumbar section -12.14 hours. The time spent in a sedentary position at home was, 3.41 hours among girls with pain located in the thoracic section and 4.43 hours among girls suffering for pain in the lumbar location. A prolonged sitting position prevailed as a posture assumed during a daily routine of the persons examined. Sleeping time in the examined group of persons with pain in the thoracic section was on average 7.27 hours and in the group 
$\frac{\sqrt[0]{0}}{\frac{\pi}{\pi}}$



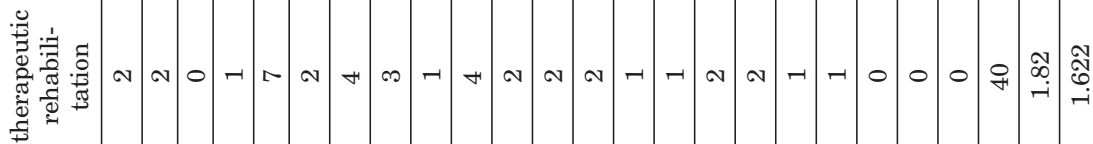

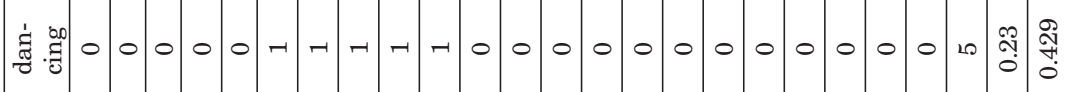
s.



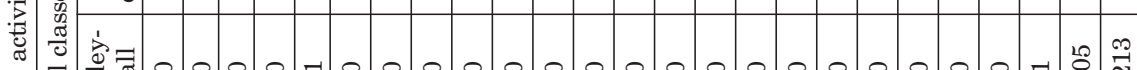
चू



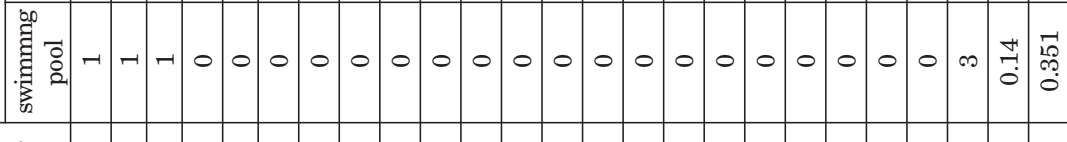



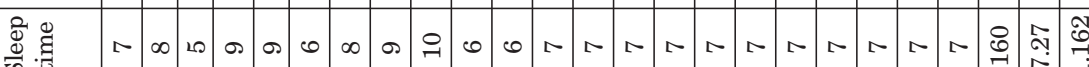
$\begin{array}{lll}-12 & -12\end{array}$

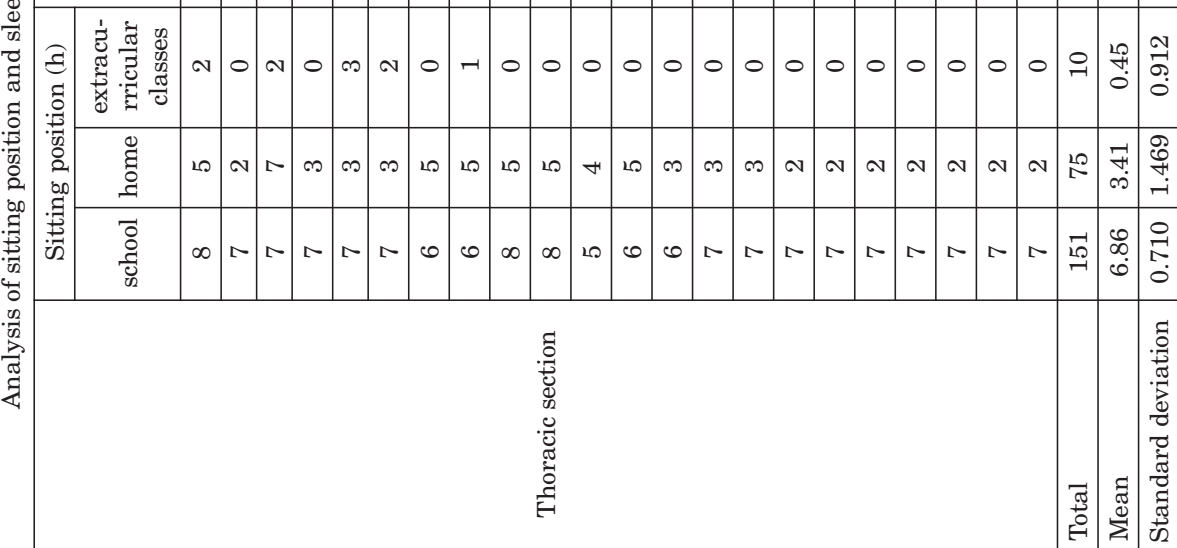


ำ

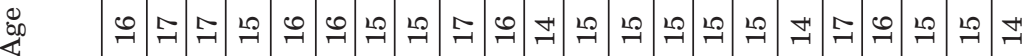

:

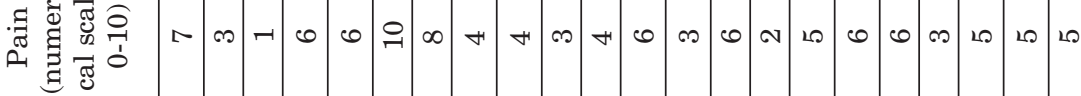

dìn

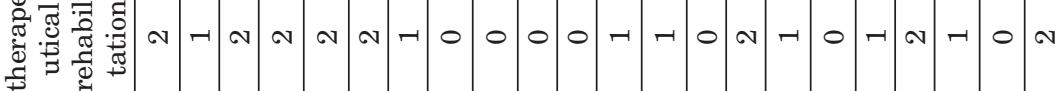

है

(10

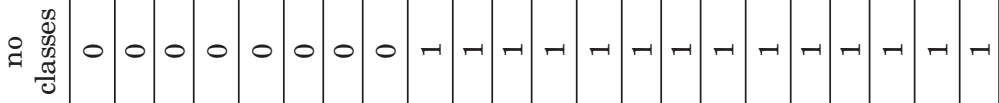

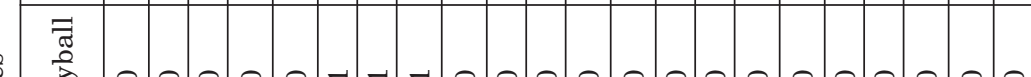

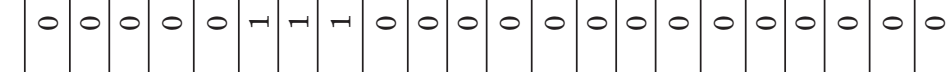

,

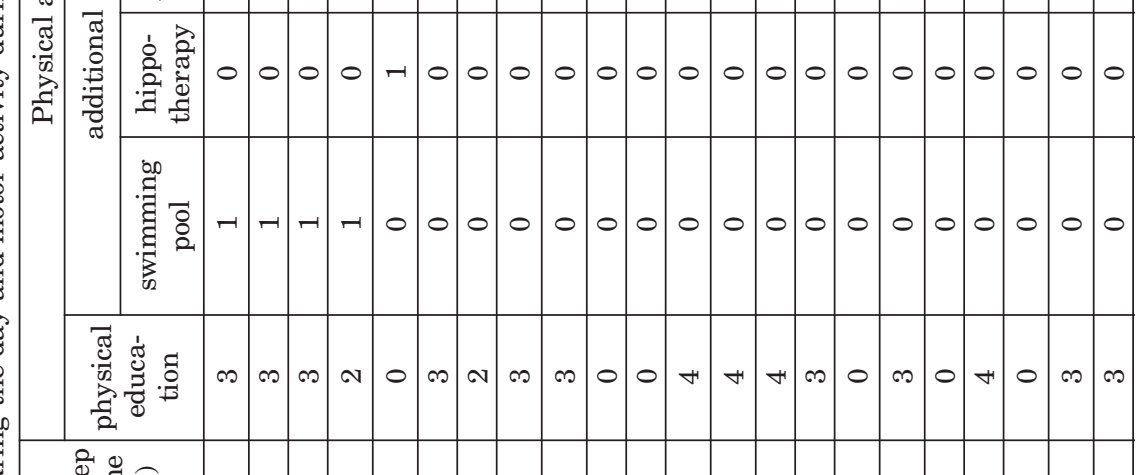

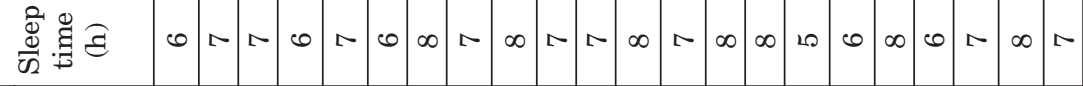

๑)

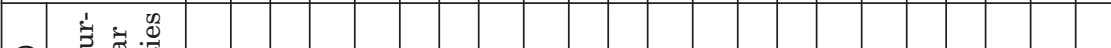

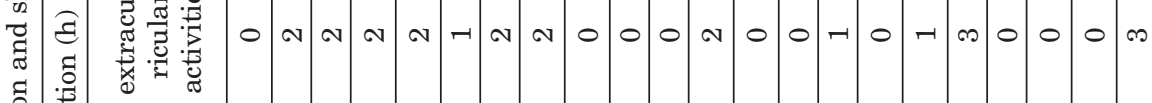

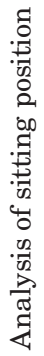





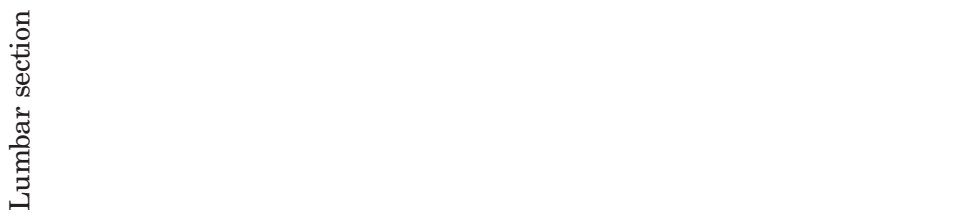




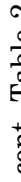

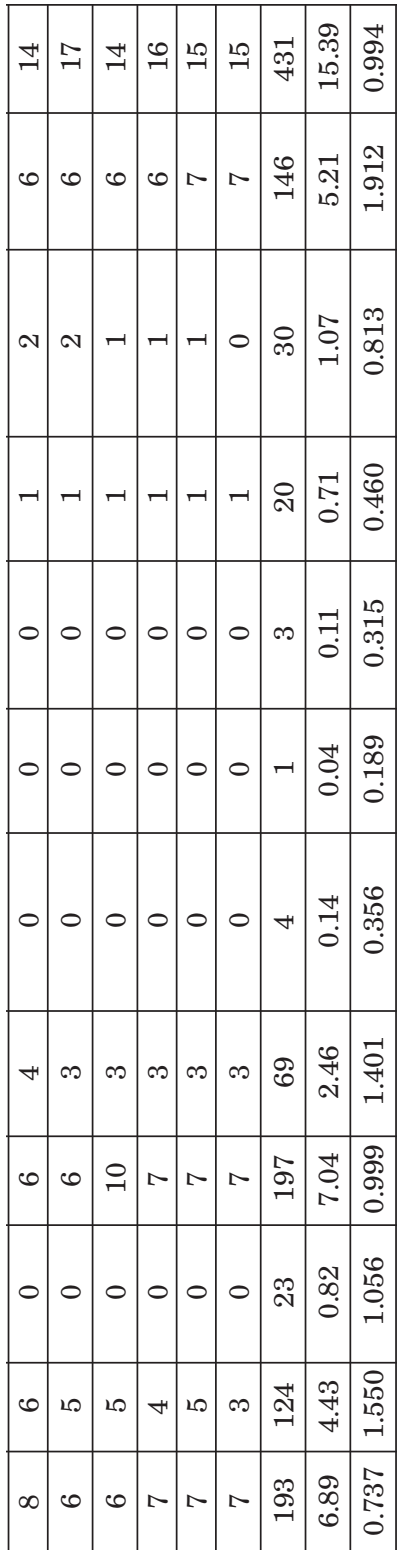


Table 3

Analysis of sitting position and sleep during the day and motor activity during a week for cervical, thoracic and lumbar sections of the spine

\begin{tabular}{|c|c|c|c|c|c|c|c|c|c|c|}
\hline \multirow{7}{*}{ 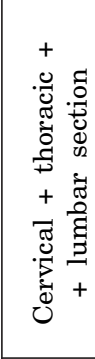 } & \multicolumn{3}{|c|}{ Sitting position (h) } & \multirow{3}{*}{$\begin{array}{l}\text { Sleep } \\
\text { time } \\
(\mathrm{h})\end{array}$} & \multicolumn{4}{|c|}{ Physical activity (h) } & \multirow{3}{*}{$\begin{array}{c}\text { Pain } \\
\text { (numeri- } \\
\text { cal scale } \\
0-10 \text { ) }\end{array}$} & \multirow{3}{*}{ Age } \\
\hline & \multirow{2}{*}{ school } & \multirow{2}{*}{ home } & \multirow{2}{*}{$\begin{array}{l}\text { extracur- } \\
\text { ricular } \\
\text { activities }\end{array}$} & & \multirow{2}{*}{$\begin{array}{l}\text { phy- } \\
\text { sical } \\
\text { educa- } \\
\text { tion } \\
\end{array}$} & \multicolumn{2}{|c|}{$\begin{array}{c}\text { additional } \\
\text { classes }\end{array}$} & \multirow{2}{*}{$\begin{array}{l}\text { thera- } \\
\text { peutical } \\
\text { rehabili- } \\
\text { tation }\end{array}$} & & \\
\hline & & & & & & $\begin{array}{c}\text { no } \\
\text { classes }\end{array}$ & dancing & & & \\
\hline & 7 & 2 & 6 & 7 & 0 & 0 & 1 & 1 & 3 & 17 \\
\hline & 7 & 2 & 3 & 5 & 2 & 1 & 0 & 2 & 7 & 16 \\
\hline & 7 & 5 & 2 & 8 & 3 & 1 & 0 & 1 & 2 & 14 \\
\hline & 8 & 2 & 0 & 6 & 3 & 1 & 0 & 0 & 6 & 16 \\
\hline Total & 29 & 11 & 11 & 26 & 8 & 3 & 1 & 4 & 18 & 63 \\
\hline Mean & 7.25 & 2.75 & 2.75 & 6.50 & 2.00 & 0.75 & 0.25 & 1.00 & 4.50 & 15.75 \\
\hline SD & 0.500 & 1.500 & 2.500 & 1.291 & 1.414 & 0.500 & 0.500 & 0.816 & 2.380 & 1.258 \\
\hline
\end{tabular}

Table 4

Qualitative composition of the diet in the examined population - part 1

Type and amount of liquids consumed during the day

\begin{tabular}{|c|c|c|}
\hline $\begin{array}{l}\text { Liquid } \\
\left(\mathrm{dm}^{3}\right)\end{array}$ & $\begin{array}{l}\text { Number } \\
\text { of persons }\end{array}$ & \begin{tabular}{|c|} 
Average \\
consumption of liquids \\
$\left(\mathrm{dm}^{3}\right)$
\end{tabular} \\
\hline $\begin{array}{l}\text { milk, cocoa } \\
0.00\end{array}$ & 26 & \multirow{3}{*}{0.17} \\
\hline 0.20 & 15 & \\
\hline 0.50 & 13 & \\
\hline $\begin{array}{l}\text { mineral water } \\
0.50\end{array}$ & 10 & \multirow{3}{*}{1.05} \\
\hline 1.00 & 25 & \\
\hline 2.00 & 7 & \\
\hline \begin{tabular}{|l} 
Juice \\
0.20
\end{tabular} & 6 & \multirow{3}{*}{0.69} \\
\hline 0.50 & 12 & \\
\hline 1.00 & 17 & \\
\hline $\begin{array}{l}\text { fizzy drinks } \\
0.25\end{array}$ & 9 & \multirow{4}{*}{0.43} \\
\hline 0.50 & 2 & \\
\hline 1.00 & 2 & \\
\hline 0.50 (sometimes) & 6 & \\
\hline cola drinks 0.25 & 7 & \multirow{4}{*}{0.42} \\
\hline 0.50 & 3 & \\
\hline 1.00 & 1 & \\
\hline 0.50 (sometimes) & 5 & \\
\hline other 0.25 & 5 & \multirow{3}{*}{0.51} \\
\hline 0.50 & 9 & \\
\hline 1.00 & 3 & \\
\hline
\end{tabular}


with pain in the lumbar section it was 7.04 hours. The average weekly time spent at physical education classes at school was 2.18 hours for persons with pain in the thoracic section and 2.46 hours in the group of girls with pain in the lumbar section (Tables 1,2). Regular breakfast time was observed by 41 persons, and lunchtime - by only 13 persons. Dinner was eaten at regular time by 32 persons and supper - by 23 . The examined girls most often drank mineral water and juice (Table 4). Dairy products, vegetables, fruit and sweets were the main constituents of their diet (Table 5).

Table 5

Qualitative composition of the diet in the examined population - part 2

\begin{tabular}{|c|c|c|c|}
\hline \multirow{26}{*}{$\begin{array}{c}\text { Frequency } \\
\text { of consuming individual } \\
\text { products in the diet }\end{array}$} & Product & $\begin{array}{l}\text { Number } \\
\text { of persons }\end{array}$ & $\begin{array}{c}\text { Average } \\
\text { consumption } \\
\text { of products }\end{array}$ \\
\hline & $\begin{array}{l}\text { dairy products, yoghurts } \\
7 \text { times a week }\end{array}$ & 34 & \multirow{4}{*}{5.22 times a week } \\
\hline & 4 times a week & 8 & \\
\hline & once a week & 1 & \\
\hline & once a month & 11 & \\
\hline & $\begin{array}{l}\text { fish } \\
\text { twice a week }\end{array}$ & 4 & \multirow{4}{*}{0.96 times a week } \\
\hline & once a week & 25 & \\
\hline & once a month & 19 & \\
\hline & never & 6 & \\
\hline & $\begin{array}{l}\text { meat } \\
7 \text { times a week }\end{array}$ & 26 & \multirow{4}{*}{4.90 times a weel } \\
\hline & 4 times a week & 11 & \\
\hline & 3 times a week & 11 & \\
\hline & 1 month & 6 & \\
\hline & $\begin{array}{l}\text { vegetables, fruit } \\
7 \text { times a week } \\
\end{array}$ & 34 & \multirow{4}{*}{5.38 times a week } \\
\hline & 4 times a week & 10 & \\
\hline & twice a week & 7 & \\
\hline & once a month & 4 & \\
\hline & $\begin{array}{l}\text { flour products } \\
7 \text { times a week }\end{array}$ & 20 & \multirow{4}{*}{5.22 times a week } \\
\hline & 4 times a week & 5 & \\
\hline & once a week & 1 & \\
\hline & once a month & 6 & \\
\hline & $\begin{array}{l}\text { sweets } \\
7 \text { times a week }\end{array}$ & 28 & \multirow{5}{*}{5.08 times a week } \\
\hline & 4 times a week & 8 & \\
\hline & 3 times a week & 1 & \\
\hline & twice a week & 2 & \\
\hline & once a month & 9 & \\
\hline
\end{tabular}


The most frequent location of back pain was the lumbar section (28 persons; $51.9 \%$ of the examined population) and the thoracic section of the spine (21 persons; $38.9 \%$ of the examined population). Simultaneous pain covering in the cervical, thoracic and lumbar sections occurred in 4 persons (7.4\% of the examined population). Double scoliosis was diagnosed in 52 girls, and cases of single and triple scoliosis were diagnosed for single patients. In 28 persons $(51.9 \%)$, it was found that the pain was reduced to the lumbar area and in $7(13 \%)$ cases, it additionally radiated to lower limbs. MRI tests performed in the later group made it possible to diagnose discopathy of this section of the spine. The examined patients with pain syndrome in the lumbar section described the intensity of pain at the level of 5 and 6 points, which corresponds to strong pain. On the other hand, girls with pain syndrome in the thoracic section described the intensity of pain at the level of 4 and 5 points, which corresponds to pain of moderate intensity (Figure 1). A prolonged sedentary position during the day was indicated as causing back pain in 20 cases (37\%). Additional activities conducted as part

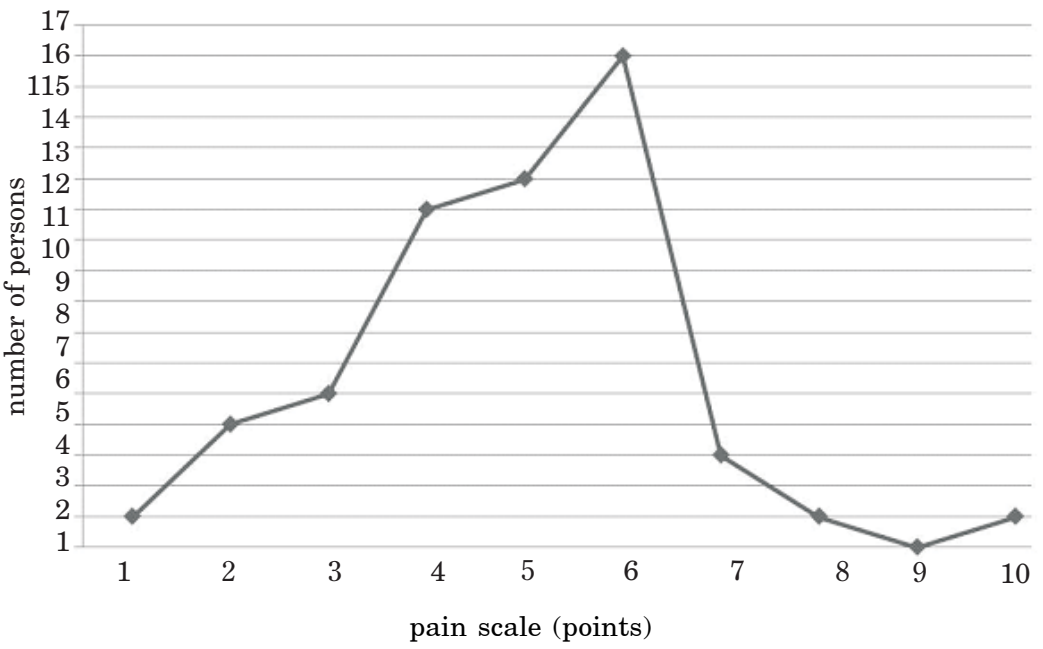

Fig. 1. Numerical rating scale of pain

of a therapeutic program were attended regularly by 36 persons (66.7\%). The average time spent on such physical activity was 1.82 hours a week for persons with pain in the thoracic section and 1.07 hours a week for persons with pain in the lumbar section. Fifty of the examined girls $(92.6 \%)$ claimed they were aware of the need to control the body posture. The correct body posture could be maintained deliberately by 23 persons $(42.6 \%)$.

The highest progress in the unbalanced nature was observed in the thoracic part of the spine, while the highest intensity of pain and changes of a neurological character were observed in the lumbar section. The results of this study indicate high intensity of pain experienced by patients who, 
despite their young age, revealed significant disorders in spinal statics. The quality and frequency of meals eaten were not related to the intensity and location of pain syndromes of the spine among the examined girls.

\section{DISCUSSION}

IS occurring during adolescence is the most frequent type of this condition, constituting at least $80 \%$ of cases diagnosed clinically (RISEBOROUGH et al. 1973). The etiology of the disease is in most cases unknown, and its symptoms often appear in previously healthy children (LONSTEIN et al. 1984). While looking for causes of the disease, researchers most often consider genetic predispositions and environmental factors, such as latitude (mostly northern) and related ambient temperature, air humidity or insolation, which, through specific mediators, affect cells of the human body (GRIVAS et al. 2006, MiLler 2000). The role of the hypothalamic neuroendocrine system, increasingly more often emphasized, should also be mentioned, as well as dysfunctions in the secretion of such substances as melatonin and leptin, since such irregularities can be accountable for more frequent occurrence of IS among girls in the adolescence period (BuRwell et al. 2008). Asymmetries found in infancy such as spinal deformations, which are revealed in the period of dynamic changes in body height during the pubertal body growth spurt, can play an important role in the development of IS (VOJTA 1988).

Essential aims of treating IS include prevention of further development of spinal curvatures, improvement of functions of the respiratory system and pain relief (WEISS et al. 2006).

The examined population of girls with diagnosed, non-invasively treated IS is characterized by a frequent occurrence of back pain and low physical activity. It is consistent with observations by WEINSTEIN et al. (2003), who explicitly confirmed significantly higher occurrence of spinal pain syndromes among persons suffering from IS in relation to the control group of healthy persons. It should be noted that the majority of cases in the examined group were diagnosed as first degree IS, but, as observed by PonsETI and FREIDMAN (1950), pain intensity in scoliosis does not depend on the angle of curvature but on its morphology and location. Curvatures located in the thoracic or lumbar sections more frequently involve the feeling of pain. This fact was also observed in the current study, in which the most frequent locations of pain included the sections of the spine described above.

The population of adolescent girls with low grade IS is a group of patients who, in survey examinations conducted by other authors, was characterized by a low level of self-esteem, frequent reporting of various types of ailments and, in consequence, depressed quality of life (GoLDBERG et al. 
1994). What should be noticed is that persons suffering from IS should receive comprehensive care, covering a full scope of non-invasive treatment (including psychotherapeutic procedures) and surgical treatment whenever appropriate (KотwICKI et al. 2008).

Damage to the central nervous system (CNS), causing subsequent developmental disturbances such as spinal deformation, can be caused by toxic elements commonly found in the natural environment. Kozielec et al. (2000) claim that an excessive amount of toxic metals, e.g. lead, cadmium, mercury, arsenic and aluminium, in the human body can disturb proper functions of the nervous and osseous systems. When accompanied by a concurrent shortage of basic bionutrients, such as calcium, magnesium, zinc, copper, iron, selenium, sulphur, cobalt, manganese and iodine, the concentration of toxic metals in the body increases. Such significant deviations from rational nutrition models, which lead to disturbances in the supply of proteins, vitamins, macro- and micronutrients (particularly in the phase of rapid growth in the developmental age) can inhibit psychomotor growth, lower the quality of bone tissue and lead to osteopenia and spinal deformations (KozIELEC et al. 2000).

Processes of environmental and health stimulation in the form of corrective kinesitherapy of spinal deformations can bring about positive effects, known as the so-called long term synaptic potentiation (LTP). This fact explains the ability to maintain the growing effectiveness of synaptic conduction for a period of some hours or days (JoHnsson et al. 2003), which has a positive influence on the process of remembering learnt patterns of proper body posture. Such results can also be expected after subsequent, repeated series of physiotherapeutic procedures, regarding as a specific type of environmental stimulation (KowALSKI et al. 2007). Perhaps, excessive stimuli from the natural environment in the form of overloading kinesiological stimulation (as overtraining) leads to a reverse process, i.e. long-term depression of synaptic transmission (LTD) (JoHNSSON et al. 2003). A prolonged sedentary position can be also regarded as a form of overtraining, which is linked with disorders related to inhibition and stimulation of muscles by the CNS. Such stimulation results in disorders of muscular tension equilibrium and disorders of motor stereotypes. An excessive amount of information from the external environment, as well as a large number of improper stimuli lead to overloads in effectors, i.e. muscles, which is frequently manifested by pain. Motor stereotypes developed by everyday improper motor models cause disorders in the physiological posture, and disorders of posture sense; consequently, they can initiate many pathologies related to spinal deformations (Johnsson et al. 2003).

Backpain, often observed in patients with IS, can be therefore regarded as a specific indicator of improper arrangement of individual skeleton parts against one another. New, proper motor patterns introduced and coded in the CNS, along with regular, everyday training of aware and positively mo- 
tivated IS patients carried out by therapists is a prerequisite of successful therapy (WIŚNIEWSKA et al. 2006). It should be also emphasized that only a radical change of everyday habits, mainly correction of improper body posture, control of the proper angle of the pelvis position, and increased time spent doing properly selected physical activity can lead to successful treatment and consequently, to improved quality of life for IS patients (WIŚNIEWSKA et al. 2006, KieBZAK et al. 2009).

\section{CONCLUSIONS}

1. Patients with pain syndrome located in the lumbar part of the spine are characterized by a longer time spent in a sedentary position, less time devoted to a programme of therapeutic rehabilitation, higher intensity of pain and higher average age as compared to the group suffering from pain in the thoracic section of the spine.

2. The lifestyle of the examined patients and lack of awareness of the need to control of the body posture can affect the type and intensity of pain.

3. Qualitative composition of the examined persons' diet had no influence on the location or the intensity of pain suffered.

\section{REFERENCES}

Burwell R.G., Dangerfield P.H., Moulton A. Anderson S.I. 2008. Etiologic theories of idiopathic scoliosis: autonomic nervous system and the leptin - sympathetic nervous system concept for the pathogenesis adolescent idiopathic scoliosis. Stud. Health. Technol. Inform., 140: 197-207.

Grivas T.B., Vasiliadis E., Savvidou O., Mouzakis V., Koufopoulos G. 2006. Geographic latitude and prevalence of adolescent idiopathic scoliosis. Stud. Health. Technol. Inform., 123: 84-89.

Goldberg M.S., Mayo N.E., Poitras B., Scott S., Hanley J. 1994. The Ste-Justine adolescent idiopathic scoliosis cohort study. Part II. Perception of health, self and body image, and participation in physical activities. Spine, 19: 1562-1572.

Johnsson G.S., Johnsson V.S. 2003. Application of principles and procedures of proprioceptive neuromuscular facilitation (PNF) in treating lumbar spine instability. Rehab. Med., 7(2): $25-45$.

Kiebzak W., Kowalski I.M., Kassolik K., Opuchlik A., ZARZYcKi D. 2009. Pain in heart regions in the course of disorders of physiological spine extension. Fizjoter. Pol. (publication pending).

Kотwicki T, Jó•WIAK M. 2008. Conservative management of neuromuscular scoliosis: personal experience and review of literature. Disabil. Rehabil., 30(10): 792-798.

Kowalski I.M., ZARZYCKI D., SzAReK J., KiebZAK W. 2007. Application of electrical stimulation in rehabilitation. Ministerstvo Zdravoochronienija Republiki Bielorus, Mediko-Socjalnaja Ekspertyza i Reabilitacja, Minsk, wypusk (9): 242-245.

Kozielec T., Radomska K., SaŁacka A., Graczyk A., Kędzierska E. 2000. Contents of bioelements and toxic metals in the body and its influence on development age health state of the Polish population. Mag. Res., 13(1): 82. 
Lonstein J.E., CARLSON J.M. 1984. The prediction of curve progression in untreated scoliosis during growth. J. Bone Joint. Surg. Am., 66: 1061-1071.

MilLeR N.H. 2000. The role of genetic factors in the etiology of idiopathic scoliosis. Spine: State Art. Rev., 14: 313-317.

Ponseti I.V., Freidman B. 1950. Prognosis in idiopathic scoliosis. J. Bone Joint. Surg. Am., 32: 381-395.

Riseborough E.J., Wynne-Davies R. 1973. A genetic survey of idiopathic scoliosis in Boston. J. Bone Joint. Surg. Am., 55: 974-982.

Weinstein S.L., Dolan L.A., Spratt K.F., Peterson K.K., Spoonamore M.J., Ponseti I.V. 2003. Health and function of patients with untreated idiopathic scoliosis: A 50-year natural history study. JAMA., 289: 559-567.

Weiss H.R., Negrim S., Rigo M., Kotwicki T., Hawes M.C., Grives T.B., Maruyama T., Landauer F. 2006. Indications for conservative management of scoliosis (guidelines). Scoliosis, 1-5.

Wiśniewska T., Kowalski I.M., WiśniewsKa M. 2006. Effects of self-therapy on the efficiency of treating spine pain syndromes. Fizjoter. Pol., 6(2): 138-142.

VоJтA V. 1988. Die zerebralen Bewegungsstorungen im Sauglingsalter: Fruhdiagnose und Fruhtherapie. Enke Stuttgart. 